\title{
Survival of Mouse Morulae and Blastocysts Derived from In Vitro Fertilization after Ultrarapid Freezing
}

\author{
N. NAKAGATA \\ Nippon Insutitute for Biological Science, 2221-1 Shin-machi, Ome-shi, Tokyo 198 and Central \\ Laboratory of Medical Sciences, Division of Pathology, Juntendo University School \\ of Medicine, 2-1-1 Hongo, Bunkyo-ku, Tokyo 113, Japan
}

(Received 28 August 1992/Accepted 4 November 1992)

\begin{abstract}
Mouse morulae and blastocysts derived from in vitro fertilization were placed in a highly concentrated vitrification solution (DAP 213:2 M dimethyl sulfoxide, $1 \mathrm{M}$ acetamide, 3 $M$ propylene glycol in PB 1) in a sampling tube at room temperature, plunged into liquid nitrogen within ten seconds and cryopreserved. Thawing was carried out by directly pouring $37^{\circ} \mathrm{C} 0.3 \mathrm{M}$ sucrose solution into the sampling tube. The ratios of morphologically normal embryos at the morula and blastocyst stages after thawing were $92.0 \%(149 / 162)$ and $13.3 \%(13 / 98)$, respectively. The rate of development from morphologically normal morulae into blastocysts in vitro was $83.1 \%(74 / 89)$. Some of the morphologically normal morulae were transferred to pseudopregnant recipients immediatly after thawing, and $45.0 \%(27 / 60)$ of the embryos developed into normal young.-KEY WORDS : mouse morula and blastocyst, ultrarapid freezing
\end{abstract}

Recently, I demonstrated that it is possible to snap-freeze 1-cell [1], 2-cell $[2,3]$, and 4 -cell mouse embryos [4] or unfertilized mouse oocytes $[5,6]$ after brief, one-step exposure to a highly concentrated solution at room temperature.

In the present study the viability of mouse morulae and blastocysts was examined.

Animals: All animals were purchased from CLEA JAPAN Inc., Japan and were maintain-ed in a barrier-system sustained animal room with relative humidity at $55 \pm 5$, temperature at $23 \pm 1^{\circ} \mathrm{C}$, and 14 hours light (3:00-17:00).

Source of the embryos: Tubal oocytes recovered from $\mathrm{B} 6 \mathrm{C} 3 \mathrm{~F}_{1}$ mice (2-3 months old) treated with PMSG (Serotropin : Teikoku Zoki Co., Japan) and hCG (Puberogen: Sankyo Zoki Co., Japan) were inseminated in vitro with epididymal spermatozoa from ICR strain mice (3 months old) and cultured for 72-96 hours in $\mathrm{HTF}$ medium [7] at $37^{\circ} \mathrm{C}$ under $5 \% \mathrm{CO}_{2}$ in air after insemination.

Freezing and thawing: The embryos devel- oped into morulae and blastocysts 72 and 96 hours after insemination and were cryopreserved by the ultrarapid freezing described previously [1]. Between 10 and 20 embryos in a small volume of $\mathrm{HTF}$ medium $(<2 \mu \ell)$ were transferred into $20-30 \mu \mathrm{l}$ of DAP $213(2 \mathrm{M}$ dimethyl sulfoxide, $1 \mathrm{M}$ acetamide, and $3 \mathrm{M}$ propylene glycol : Sigma, USA) in PB 1 [1] in sampling tubes (volume $0.5 \mathrm{~m} \ell$ : Cat. No. 72 . 699 , Sarstedt, Germany) at room temperature, and the samples were plunged directly into liquid nitrogen. The duration of oocyte exposure to DAP 213 before freezing was 5-10 seconds. The samples were stored for 2-3 weeks before thawing. They were thawed and diluted by direct addition of $0.3 \mathrm{ml}$ of $37^{\circ} \mathrm{C} 0.3$ $M$ sucrose solution to the sampling tubes immediately after removal from liquid nitrogen. The contents of each tube were emptied into a culture dish $(35 \times 10 \mathrm{~mm}$, Falcon) and the tubes were rinsed once with $0.3 \mathrm{~m} \ell$ of $0.3 \mathrm{M}$ sucrose solution. The recovered embryos were washed by transfer through four changes of HTF medium, and the number of oocytes and their 
Table 1. Survival rates of frozen-thawed mouse embryos at the morula and blastocyst stage after thawing

\begin{tabular}{cccc}
\hline \multirow{2}{*}{$\begin{array}{l}\text { Embryo } \\
\text { stage at the } \\
\text { time of freezing }\end{array}$} & $\begin{array}{l}\text { No. of } \\
\text { embryos } \\
\text { frozen }\end{array}$ & recovered (\%) & morphologically normal (\%) \\
\cline { 3 - 4 } & & $162(97.6)$ & $149(92.0)$ \\
Morula & 166 & $98(96.1)$ & $13(13.3)$ \\
Blastocyst & 102 & &
\end{tabular}
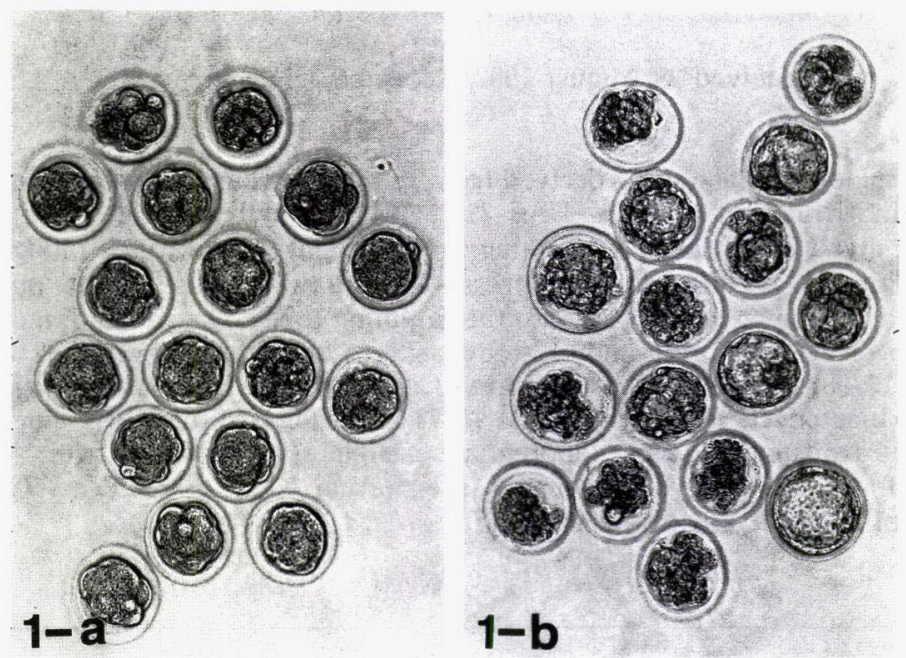

Fig. 1. Frozen-thawed mouse embryos at the morula and blastocyst stage after thawing. Most of the frozen-thawed morulae are morphologically normal (a), but there are few morphologically normal blastocysts (b) .

Table 2. Development of frozen-thawed morulae into blastocysts in vitro

\begin{tabular}{cc}
\hline $\begin{array}{l}\text { No. of embryos } \\
\text { cultured }\end{array}$ & $\begin{array}{l}\text { No. }(\%) \text { of embryos which } \\
\text { developed into blastocysts }\end{array}$ \\
\hline 89 & $74(83.1)$ \\
\hline
\end{tabular}

Table 3. Development into live young of frozen-thawed morulae after transfer to pseudopregnant recipients

\begin{tabular}{|c|c|c|c|c|c|}
\hline \multirow{2}{*}{$\begin{array}{l}\text { No. of } \\
\text { embryos } \\
\text { transferred }\end{array}$} & \multirow{2}{*}{$\begin{array}{l}\text { No. of } \\
\text { recipients } \\
\text { used }\end{array}$} & \multirow{2}{*}{$\begin{array}{l}\text { No. of animals } \\
\text { which delivered } \\
\text { live young }\end{array}$} & \multicolumn{3}{|c|}{ No. of live young } \\
\hline & & & 우 & $\sigma^{7}$ & $\operatorname{total}(\%)$ \\
\hline 60 & 4 & 4 & 11 & 16 & $27(45.0)$ \\
\hline
\end{tabular}

morphological appearance were recorded.

Morphologically normal cryopreserved morulae were introduced into fresh HTF medium and cultured for 24 hours, and some of the morphologically normal morulae were tran- sferred to the uterine horns of the recipients on day 3 of pseudopregnancy (day 1 was the day on which the vaginal plug was found) .

The proportions of morulae and blastocysts which appeared morphologically nor- 
mal after freezing and thawing are shown in Table 1 . The viability was high for morulae, and $92.0 \%(149 / 162)$ of the recovered embryos were morphologically normal (Fig. 1-a). The viability of blastocysts, however, was very low, and only $13.3 \%(13 / 98)$ of recovered embryos were morphologically normal (Fig. 1-b). Tables 2 and 3 show the in vitro and in vivo viability assay for frozen-thawed morulae. The proportion of cryopreserved morulae which developed into blastocysts after culture in vitro was $83.1 \%(74 / 89$, Table 2$)$, and the rate of survial to normal young following transfer was $57.5 \%(46 / 80$, Table 3$)$.

Whittingham reported survival rates for frozen-thawed mouse blastocysts of between $69 \%$ and $76 \%$ after storage at $-196{ }^{\circ} \mathrm{C}$, when the slow-freezing and slow-thawing method was used [9]. Schiffen et al. also reported that mouse blastocysts can be cryopreserved successfully using the simple technique of vitrification, but the survival rate after warming was low $(39 \%)$ [8]. In the present study, the viability of blastocysts cryopreserved using the ultrarapid freezing method was lower after thawing than in these reports. Because of this, it is conceivable that blastocyst sensitivity to freezing may vary markedly depending on the method of freezing. Further study is needed to improve the survival of blastocysts when using the ultrarapid freezing method.

I wish to thank Dr. Yutaka Toyoda (Institute of Medical Science, University of Tokyo, Tokyo, Japan), Dr. Yoshiro Fukuda, Mrs. Yaeko Murata (Juntendo University, School of Medicine, Tokyo, Japan) and Dr. Susumu Ueda (Nippon Insutitute for Biological Science), for their advice. This work was supported by a Grant-in-Aid for Scientific Research from the Ministry of Education, Science and Culture of Japan.

\section{References}

[1] Nakagata, N. (1989). Jpn. J. Fert. Steril., 34, 757-760.

[2] Nakagata, N. (1989). Jpn. J. Fert. Steril., 34, 470-473.

[3] Nakagata, N. (1990). Exp. Anim., 39, 299-301.

[4] Nakagata, N. (1990). Exp. Anim., 38, 279-282.

[5] Nakagata, N. (1989). J. Reprod. Fert., 87, 479-483.

[6] Nakagata, N. (1990). Exp. Anim., 39, 303-305.

[7] Quinn, P, Kerin, J. F., and Warnes, G. M. (1985). Fert. Steril., 44, 493-498.

[8] Scheffen, B., Van Der Zwalman, P., and Massip, A. (1989). Cryo-letters, 7, 260-269

[9] Whittingham, D. G. (1974). J. Reprod. Fert., 37, 159-162.

\title{
マウス桑実胚および肧盤胞期肧の超急速凍結保存
}

\author{
中潟直已
}

日本生物科学研究所

順天堂大学医学部共同病理研究室

室温にて高濃度の保存液 (DAP 213：2 M dimethyl sulfoxide, $1 \mathrm{M}$ acetamide, $3 \mathrm{M}$ propylene glycol in $\mathrm{PBl}$ ) に胚を移し，10 秒以内に, 直接液体窒素に浸漬 することにより, マウス桑実肧および肧盤胞の凍結保 存を行った。また, 融解は保存容器内に $37^{\circ} \mathrm{C} の 0.3 \mathrm{M}$ sucrose 溶液を加之, 融解と同時に保存液の希釈を 行った。桑実肧における融解時の形態的正常肧の割合
は, $92.0 \%(149 / 162)$ と高值であり, それら胚の体外 培養による胚盤胞への発生率および移植による新生 児への発生率はそれぞれで $83.1 \%(74 / 89)$ および 45.0\% (27/60)であった。しかしながら, 胚盤胞にお ける融解時の形態的正常胚の割合は，わずか $13.3 \%$ （13/98）と低值であった。 